\title{
Fish consumption and lifestyle: a cross-sectional study
}

\author{
Erika da Silva MACIEL ${ }^{1 *}$, Jaqueline Girnos SONATI ${ }^{2}$, Juliana Antunes GALVÃO ${ }^{3}$, Marília OETTERER $^{3}$
}

\begin{abstract}
Introduction: regular fish consumption has been associated with health benefits and prevention of risk factors of chronic diseases; however, consumption is heterogeneous worldwide. Consumption is higher among populations that have fish as a traditional food or among people who tend to adopt a more active and healthy lifestyle. Objectives: to evaluate the level of physical activity and perception of life quality among groups with higher and lower frequency of fish consumption. Material and methods: quantitative and cross-sectional study carried out via the Internet using the WHOQOL-bref tools to assess perception of life quality. The IPAQ short version normal week was used to evaluate the level of physical activity and proper tool to assess fish consumption. The frequency of fish consumption stratified into two groups (higher and lower frequency) was used as predictor variable. As outcome variable, it was considered the perception of life quality and level of physical activity among groups. Results: the group of participants with the highest fish consumption presented better perception of life quality and are more physically active. Discussion and conclusion: the results reinforces that regular fish consumption may be related to healthier lifestyle that, consequently, lead to a better perception of life quality.
\end{abstract}

Keywords: life quality; fish consumption; health promotion.

Practical Application: Actions to encourage fish consumption can have an impact on improving the quality of life.

\section{Introduction}

International dietary recommendations suggest that regular fish consumption provides high quality protein as well as essential nutrients for health (Thorsdottir et al., 2009) and these benefits are the main drives for the population to buy fish (Olsen et al., 2017).

Fish consumption is linked to reduction of risks of coronary heart disease (CHD) and improvement of neurological development (Hellberg et al., 2012). Studies suggested that fish consumption, especially species rich in polyunsaturated fatty acids, is inversely associated with the risk factors for metabolic syndrome (Kouki et al., 2011; Zaribaf et al., 2014), which is corroborated by systematic meta-analytic reviews, particularly when fish consumption is associated to other healthy life habits (Torris et al., 2014; Torrissen \& Onozaka, 2017; Kim et al., 2015; Hellberg et al., 2012).

International institutions, such as IOM (Institute of Medicine) and $\mathrm{FAO} / \mathrm{WHO}$ (Food and Agriculture Organization of the United Nations/World Health Organization), have suggested regular fish consumption at least twice a week in order to reach benefits (Hellberg et al., 2012).

Despite information based on scientific research regarding its importance and relevance to health, fish consumption displays a distinguished behavior worldwide (Maciel et al., 2016). Countries with native communities, for example, have an average consumption per capita 15-fold greater than those with urban populations (Cisneros-Montemayor et al., 2016). Fish is also part of the traditional diet in Asian countries. However, despite its high quality, fish is not part of the usual diet and culture of many western countries, as observed in Australia (Birch \& Lawley, 2013) and Brazil (Maciel et al., 2013).

In addition, $\mathrm{FAO}$ indicates a relationship with fish consumption and economic development. In 2009, in European and North America countries, fish consumption reached $22-24 \mathrm{~kg}$ person/year, in developing countries, fish consumption was $17 \mathrm{~kg}$ person/year and in low-income countries with food shortages, $10.1 \mathrm{~kg}$ (Barbaroux et al., 2012).

It is assumed, therefore, that fish consumption is influenced by lifestyle-related indicators, socio-demographic issues and previous experiences with fish products (Myrland et al., 2000; Cardoso et al., 2016).

Given that fish consumption can be an important part of a healthy lifestyle, it is hypothesized that individuals with higher fish consumption tend to have higher level of physical activity and higher scores in the perception of life quality (Maciel et al., 2016). Thus, this study evaluated the level of physical activity and perception of life quality among groups of higher and lower frequency of fish consumption 


\section{Materials and methods}

\subsection{Study design}

Quantitative study of transverse character carried out according to the guidelines of STROBE statement (von Elm et al., 2007).

\subsection{Setting}

The data were collected via the Internet through the SurveyMonkey ${ }^{\circledast}$ system. Volunteers were invited by electronic means through dissemination of research directed to communication offices of 112 Federal Universities of Brazil and the Brazilian Agricultural Research Company (EMBRAPA).

\subsection{Respondents}

The study comprised 944 volunteer participants who responded to the structured research electronically.

The eligibility criteria were: be over 18 years old, respond to on-line instruments through websites, and belong to one of the groups established after analysis of fish consumption, as described below: Group $1(n=118)$ consume fish 2 times a week or more, and Group $2(n=113)$ consume fish less than 1 time per week. As they did not fit in either group, 713 volunteers were excluded from the study.

The criteria used aimed to minimize a possible sample bias, once this is a study with a sample of convenience; therefore, possibly participants who have affinity for the theme also represented greater frequency in the sample, interfering in the results. Thus, extreme points in relation to fish consumption were used.

Participants had access to the Terms of Free and Clarified Consent (TFCC) available on the research homepage and, only after reading and accepting, the forms were made available. This study obtained approval of the Committee of Ethics in Research (protocol 087) respecting procedures for human beings of legislation number 466/2012.

\subsection{Assessment}

To assess fish consumption, Perception Survey of Fish Consumption - (PSFC) (Maciel et al., 2014) with adaptations. This survey evaluates the frequency and characteristics of fish consumption in auto reference.
The perception of life quality was assessed through WHOQOL-bref (Pio et al., 1999) that covers four aspects: physical, psychological, social relations and environment, as well as life quality in general.

The level of physical activity was assessed by International Physical Activity Questionnaire (IPAQ) in its short version (Pardini et al., 2001).

The results were calculated based on Metabolic Equivalent (MET) that refers to the amount of oxygen required, per minute, under normal rest, equal to $3.5 \mathrm{ml}$ of oxygen consumed per kilogram of body weight per minute $(\mathrm{ml} / \mathrm{kg} \mathrm{min})$. The higher the MET, the greater the oxygen consumption; therefore, there is greater calorie burning and, consequently, a higher level of physical activity (Monteiro et al., 2003).

\subsection{Statistical methods}

The frequency of fish consumption stratified into two groups (higher and lower frequency of use) was used as predictor variable. As outcome variable, it was considered the perception of life quality and level of physical activity among consumer groups and, finally, as confounding variables, educational level, sex and age were considered.

The analysis included adherence test to normal distribution (Kolmogorov and Smirnoff tests), homoscedasticity test, and later, comparison between the groups. The Mann-Whitney test was used for non-parametric variables and the Student T-test for parametric variables. The Chi square test was used for categorical variables.

\section{Results}

The perception of life quality, when compared between groups of higher and lower consumption, showed higher averages in all areas for the group with the highest fish consumption, with statistically significant difference (Table 1).

Following the same trend, Group 1 showed the highest number of individuals with moderate and high physical activity levels, meaning that fish consumers more often tend to be more physically active (Table 2).

The analysis of confounding variables, between selected groups (Table 3 ), showed that the groups are different regarding sex, educational level and age. Therefore, the largest consumption group was characterized by women, higher education and higher average age.

Table 1. Comparison of perception of life quality among fish consumers, Brazil, 2016.

\begin{tabular}{|c|c|c|c|c|c|c|}
\hline \multirow{3}{*}{ Aspects } & \multicolumn{2}{|c|}{ Group $1^{*}$} & \multicolumn{2}{|c|}{ Group $2^{\star *}$} & \multirow{3}{*}{ Test } & \multirow{3}{*}{$\mathrm{p}$ - value } \\
\hline & \multicolumn{2}{|c|}{$\mathrm{n}=118$} & \multicolumn{2}{|c|}{$\mathrm{n}=113$} & & \\
\hline & average & $\mathrm{SD}$ & average & $\mathrm{SD}$ & & \\
\hline Physical & 17.09 & 2.04 & 16.49 & 2.59 & Mann-Whitney & 0.006 \\
\hline Psychological & 16.49 & 1.84 & 15.63 & 2.05 & Mann-Whitney & $<0.001$ \\
\hline Social relationships & 16.06 & 2.68 & 15.16 & 2.55 & Mann-Whitney & 0.002 \\
\hline Environment & 14.80 & 2.09 & 13.64 & 2.44 & Test-t student & $<0.001$ \\
\hline Life quality in general & 16.88 & 2.45 & 15.39 & 2.98 & Mann-Whitney & $<0.001$ \\
\hline
\end{tabular}

${ }^{*}>$ consumption $=2 \mathrm{x} /$ week or more; ${ }^{* *}<$ consumption $=$ less than $1 \mathrm{x} /$ week. 
Table 2. Comparison of levels of physical activity among fish consumers, Brazil, 2016.

\begin{tabular}{|c|c|c|c|c|c|c|}
\hline \multirow{3}{*}{$\begin{array}{l}\text { Level of physical } \\
\text { activity }\end{array}$} & \multicolumn{2}{|c|}{ Group $1^{*}$} & \multicolumn{2}{|c|}{ Group $2^{* *}$} & \multirow{3}{*}{ Test } & \multirow{3}{*}{ p-value } \\
\hline & \multicolumn{2}{|c|}{$\mathrm{n}=118$} & \multicolumn{2}{|c|}{$\mathrm{n}=113$} & & \\
\hline & $\mathrm{n}$ & $\%$ & $\mathrm{n}$ & $\%$ & & \\
\hline Light & 36 & 30.5 & 47 & 41.6 & & \\
\hline Moderate & 42 & 35.6 & 45 & 39.8 & Chi square & 0.025 \\
\hline High & 40 & 33.9 & 21 & 18.6 & & \\
\hline
\end{tabular}

${ }^{*}>$ consumption $=2 \mathrm{x} /$ week or more ${ }^{* *}<$ consumption $=$ less than $1 \mathrm{x} /$ week.

Table 3. Analysis of confounding variables between groups, Brazil, 2016.

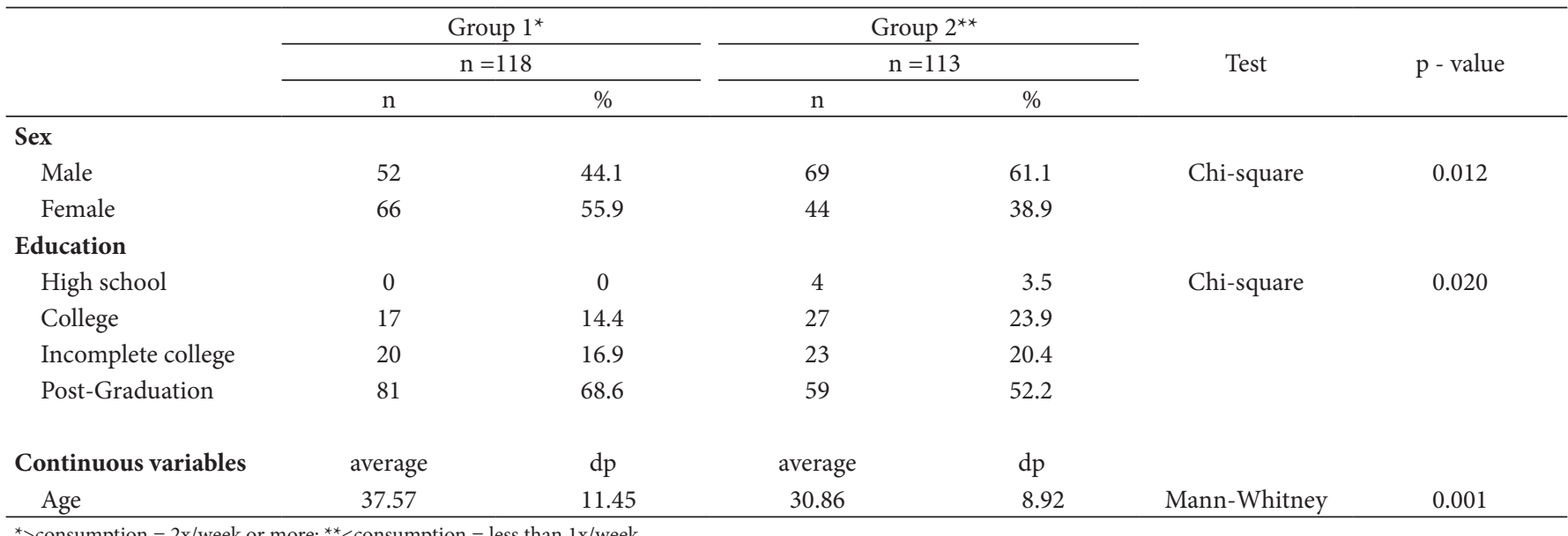

${ }^{*}>$ consumption $=2 \mathrm{x} /$ week or more ${ }^{* *}<$ consumption $=$ less than $1 \mathrm{x} /$ week.

\section{Discussion}

The group of participants with highest fish consumption presented better perception in all aspects of quality of life, including the aspects of physical and quality of life in general, which consist of facets about the perception of health, such as pain and discomfort, energy and fatigue, sleep and rest.

The results also indicate that participants with higher consumption are more physically active, reinforcing the idea that regular fish consumption may be related to healthier living habits, which represents a better perception of life quality.

A study with Brazilian and Portuguese fish consumers identified association between higher consumption and higher levels of physical activity, as well as higher scores of life quality perception (Maciel et al., 2016).

The results indicate that higher fish consumption can be associated to a more active lifestyle and these habits, when combined, can strengthen the protective effects to health, collaborating with proper maintenance of cholesterol levels and triglycerides.

However, these data should be viewed with caution, because the study presents as limitation the fact that information is auto-referenced, eventually adding bias to the response. The stratification of groups with higher and lower consumption showed that the possible bias was minimized. In addition, our study did not consider the consumption assessment of other foods.

Although our study did not aim to assess the risk factors for metabolic syndrome, when food consumption is considered, inverse association between fish consumption, rich in polyunsaturated fatty acids, and the presence of metabolic syndrome have also been highlighted in misanalyse studies (Kim et al., 2015; Torris et al., 2014).

Omega-3 fatty acids from fish oil, comprising docosahexaenoic acid (DHA) and eicosapentaenoic acid (EPA), play a positive effect on prevention of cardiovascular disease, such as decreased platelet aggregation and systemic blood pressure, improving endothelial function, plaque stabilization of atherosclerotic and triglycerides (Santos et al., 2013).

These benefits, combined with fish protein quality of high biological value (Martins \& Oetterer, 2009), make fish an essential food, especially when the objective is health promotion.

The aspects related to level of physical activity show clear evidences of health benefits with a risk reduction for over 25 chronic diseases and premature mortality (Warburton \& Bredin, 2016).

Considering that a sedentary lifestyle is associated with several chronic diseases, such as the metabolic syndrome (Rao et al., 2016) and that sedentarism has increased in contemporary societies (Ekelund et al., 2016), studies should discuss protection factors and associations in order to guide the development of preventive policy. Thirty-eight million deaths worldwide have been attributed to chronic non-communicable diseases (NCD), mainly cardiovascular, cancer and chronic respiratory diseases. Roughly three quarters of these deaths (28 million) occurred in low-and middle-income countries (World Health Organization, 
2014), which shows the need to invest in preventive actions and lower costs.

Metabolic syndrome is an early risk indicator of chronic disease and describes the coexistence risk factors for cardiovascular disease (Rao et al., 2016). When at least three of five factors are associated (abdominal obesity, hypertension, hyperglycemia, increased triglycerides and HDL), the syndromes is characterized (Kimokoti et al., 2015; Mahabaleshwarkar et al., 2016).

The inverse association between risk factors for metabolic syndrome and regular fish consumption was observed in a study of systematic review with meta-analysis (Kim et al., 2015; Torris et al., 2014), and in specific regions such as Finland (Kouki et al., 2011) and Iran (Zaribaf et al., 2014). However, the same was not evidenced in Latin American countries (Lai et al., 2013). Such evidence provide basis for studies on different populations, taking into account lifestyle practiced in the region.

Regular physical activity stands out among protection factors for chronic diseases (Dumith, 2009; Ekelund et al., 2016; Rao et al., 2016) and maintenance of serum levels of lipids (Associação Brasileira para o Estudo da Obesidade e Síndrome Metabólica, 2016; Xavier et al., 2013). The latter can be achieved with regular physical activity and, mainly, by consuming foods rich in polyunsaturated fatty acids, such as fish and by-products (Raatz et al., 2013; Zaribaf et al., 2014).

Although evidence of fish consumption is positive, in Brazil, regular fish consumption, referred to at least once a week, was present in $54.6 \%$ of adult population, and lower among younger people, $47 \%$, without education or with incomplete elementary school, 51.5\%, and rural area residents, 50.8\% (Jaime, 2015).

In our study, the group with higher fish consumption had higher schooling levels and higher average age.

A study conducted in Norway showed that fish consumption can be stimulated through campaigns focused on lifestyle indicators, among these, products with high quality and added nutritional value. In addition, consumption is greater among participants of older age, which reflects consumption habits (Myrland et al., 2000).

Overall, it is not possible to generalize the results found in this study. Brazil is a country of great population density and with regional differences that are not taken into account. Still, as the survey was conducted via the Internet, it assumes the exclusion of a social class that does not have access to this means of communication. Moreover, participants of the survey possibly have affinity with the theme addressed, which motivates them to participate in the study, and those who are not interested are automatically excluded.

However, the results presented here are supported by current scientific literature and add a positive outcome in relation to the perception of life quality.

\section{Conclusion}

Participants with regular fish consumption were more active physically and with better life quality perception. These results may be a reflection of the lifestyle practiced by the participants; moreover, consumers frequently tend to be women, older and with educational formation. These results suggest that modifications in lifestyle, via fish consumption, can provide positive aspects to health and improve life quality in general.

\section{References}

Associação Brasileira para o Estudo da Obesidade e Síndrome Metabólica - ABESO. (2016). Diretrizes brasileiras de obesidade 2016/ABESO (4. ed., 188 p.). São Paulo: ABESO.

Barbaroux, O., Bizzarri, G., Hasan, M. R., Miuccio, L., Saha, J., \& Sanders, J., Spaull, J., \& Acker, J. Van. (2012). The state of world fisheries and aquaculture. Rome: FAO. Cover photographs courtesy of FAO. Retrieved from http://www.fao.org/3/a-i2727e.pdf

Birch, D., \& Lawley, M. (2013). The role of habit, childhood consumption, familiarity, and attitudes across seafood consumption segments in Australia. Journal of Food Products Marketing, 20(1), 98-113. http:// dx.doi.org/10.1080/10454446.2012.732548.

Cardoso, C., Lourenço, H., Costa, S., Gonçalves, S., \& Leonor Nunes, M. (2016). Survey into the seafood consumption preferences and patterns in the portuguese population: education, age, and health variability. Appetite, 22(4), 421-435. https://doi.org/10.1016/j. appet.2012.12.022.

Cisneros-Montemayor, A. M., Pauly, D., Weatherdon, L. V., Ota, Y., Marsh, R., \& McCauley, D. (2016). A global estimate of seafood consumption by coastal indigenous peoples. PLoS One, 11(12), e0166681. http:// dx.doi.org/10.1371/journal.pone.0166681. PMid:27918581.

Dumith, S. C. (2009). Physical activity in Brazil: a systematic review. Cadernos de Saúde Pública, 25(Supl 3), S415-S426.

Ekelund, U., Steene-johannessen, J., Brown, W. J., Fagerland, M. W., Owen, N., Powell, K. E., \& Lee, I. (2016). Does physical activity attenuate, or even eliminate, the detrimental association of sitting time with mortality? A harmonised meta-analysis of data from more than 1 million men and women. Lancet, 6736(16), 1-10. PMid:27475271.

Hellberg, R. S., Dewitt, C. A. M., \& Morrissey, M. T. (2012). RiskBenefit Analysis of Seafood Consumption: A Review. Comprehensive Reviews in Food Science and Food Safety, 11(5), 490-517. http:// dx.doi.org/10.1111/j.1541-4337.2012.00200.x.

Jaime, P. C. (2015). Prevalência e distribuição sociodemográfica de marcadores de alimentação saudável, Pesquisa Nacional de Saúde, Brasil 2013. Epidemiologia e Serviços de Saúde, 24(2), 267-276. http:// dx.doi.org/10.5123/S1679-49742015000200009.

Kim, Y.-S., Xun, P., \& He, K. (2015). Fish consumption, long-chain omega-3 polyunsaturated fatty acid intake and risk of metabolic syndrome: a meta-analysis. Nutrients, 7(4), 2085-2100. http://dx.doi. org/10.3390/nu7042085. PMid:25811108.

Kimokoti, R. W., Judd, S. E., Shikany, J. M., \& Newby, P. K. (2015). Metabolically healthy obesity is not associated with food intake in white or black men. The Journal of Nutrition, 145(11):2551-2261. http://dx.doi.org/10.3945/jn.115.221283.

Kouki, R., Schwab, U., Hassinen, M., Komulainen, P., Heikkilä, H., Lakka, T., \& Rauramaa, R. (2011). Food consumption, nutrient intake and the risk of having metabolic syndrome: the DR's EXTRA study. European Journal of Clinical Nutrition, 65262(10), 368-377. http://dx.doi.org/10.1038/ejcn.2010.262. PMid:21119694.

Lai, Y. H. L., Petrone, A. B., Pankow, J. S., Arnett, D. K., North, K. E., Ellison, R. C., Hunt, S. C., \& Djoussé, L. (2013). Association of dietary omega-3 fatty acids with prevalence of metabolic syndrome: the national heart, lung, and blood institute family heart study. 
Clinical Nutrition (Edinburgh, Lothian), 32(6), 966-969. http://dx.doi. org/10.1016/j.clnu.2013.05.002. PMid:23711994.

Maciel, E. D. S., Vilarta, R., Modeneze, D. M., Sonati, J. G., Vasconcelos, J. S., Vilela, G. B., Jr., \& Oetterer, M. (2013). The relationship between physical aspects of quality of life and extreme levels of regular physical activity in adults. Cadernos de Saude Publica, 29(11), 2251-2260. http://dx.doi.org/10.1590/0102-311x00178512. PMid:24233040.

Maciel, E. S., Sonati, J. G., Modeneze, D. M., Quaresma, F. R. P., Oetterer, M., \& Vilarta, R. (2016). Cross-sectional study for assessment of fish consumption in terms of the level of physical activity and perception of quality of life in volunteers in Brazil and Portugal. Integrative Food, Nutrition and Metabolism, 3(2), 289-294. http:// dx.doi.org/10.15761/IFNM.1000145.

Maciel, S., Vasconcelos, J. S., Kimie, L., Sonati, J. G., Galvão, J., Silva, D., \& Oetterer, M. (2014). Designing and validating the methodology for the Internet assessment of fish consumption at a university setting. Food Science and Technology, 34(2), 315-323. http://dx.doi. org/10.1590/fst.2014.0053.

Mahabaleshwarkar, R., Taylor, Y. J., Spencer, M. D., \& Mohanan, S. (2016). Prevalence of Metabolic Syndrome in a Large Integrated Health Care System in North, 77(3), 168-174.

Martins, W. S., \& Oetterer, M. (2009). Correlação entre o valor nutricional e o preço de oito espécies de pescado comercializados no estado de São Paulo. Boletim do Instituto de Pesca, 36(4), 277-282.

Monteiro, C. A., Conde, W. L., Matsudo, S. M., Matsudo, V. R., Bonseñor, I. M., \& Lotufo, P. A. (2003). A descriptive epidemiology of leisuretime physical activity in Brazil, 1996-1997. Revista Panamericana de Salud Pública, 14(4), 246-254.

Myrland, Ø., Trondsen, T., Johnston, R. S., \& Lund, E. (2000). Determinants of seafood consumption in Norway: lifestyle, revealed preferences, and barriers to consumption. Food Quality and Preference, 11(3), 169-188. http://dx.doi.org/10.1016/S0950-3293(99)00034-8.

Olsen, S. O., Tuu, H. H., \& Grunert, K. G. (2017). Attribute importance segmentation of Norwegian seafood consumers: the inclusion of salient packaging attributes. Appetite, 117, 214-223. http://dx.doi. org/10.1016/j.appet.2017.06.028. PMid:28669742.

Pardini, R., Matsudo, S., Matsudo, V., Andrade, E., Braggion, G., \& Andrade, D. (2001). Validação do questionário internacional de nível de atividade física (IPAQ - versão 6): estudo piloto em adultos jovens brasileiros. Revista Brasileira de Ciência e Movimento, 9(3), 45-51.

Pio, M., Fleck, D. A., Leal, O. F., Louzada, S., Xavier, M., \& Chachamovich, E. (1999). Desenvolvimento da versão em português do instrumento de avaliação de qualidade de vida da OMS (WHOQOL-100). Brazilian Journal of Psychiatry, 21(1), 19-28.

Raatz, S., Silverstein, J., Jahns, L., \& Picklo, M. J. (2013). Issues of fish consumption for cardiovascular disease risk reduction. Nutrients, 5(4), 1081-1097. http://dx.doi.org/10.3390/nu5041081. PMid:23538940.
Rao, D. P., Orpana, H., \& Krewski, D. (2016). Physical activity and non-movement behaviours : their independent and combined associations with metabolic syndrome. The International Journal of Behavioral Nutrition and Physical Activity, 13(1), 1-11. http://dx.doi. org/10.1186/s12966-016-0350-5. PMid:26893071.

Santos, R. D., Gagliardi, A. C., Xavier, H. T., Magnoni, C. D., Cassani, R., \& Lottenberg, A. M. (2013). I Diretriz sobre o consumo de gorduras e saúde cardiovascular. Sociedade Brasileira de Cardiologia, 100 (Supl 3), 1-40.

Thorsdottir, I., Birgisdottir, B., Kiely, M., Martinez, J., \& Bandarra, N. (2009). Fish consumption among young overweight European adults and compliance to varying seafood content in four weight loss intervention diets. Public Health Nutrition, 12(5), 592-598. http://dx.doi.org/10.1017/S136898000800253X. PMid:18561865.

Torris, C., Molin, M., \& Cvancarova Smastuen, M. (2014). Fish consumption and its possible preventive role on the development and prevalence of metabolic syndrome - a systematic review. Diabetology \& Metabolic Syndrome, 6(1), 112. http://dx.doi.org/10.1186/17585996-6-112. PMid:25352919.

Torrissen, J. K., \& Onozaka, Y. (2017). Comparing fish to meat: perceived qualities by food lifestyle segments. Aquaculture Economics \& Management, 21(1), 44-70. https://doi.org/10.1080/13657305.20 17.1265022.

von Elm, E., Altman, D. G., Egger, M., Pocock, S. J., Gøtzsche, P. C., \& Vandenbroucke, J. P. (2007). The Strengthening the Reporting of Observational Studies in Epidemiology (STROBE) Statement: guidelines for reporting observational studies. PLoS Medicine, 4(10), e296. http://dx.doi.org/10.1371/journal.pmed.0040296. PMid:17941714.

Warburton, D. E. R., \& Bredin, S. S. D. (2016). Reflections on physical activity and health: what should we recommend? The Canadian Journal of Cardiology, 32(4), 495-504. http://dx.doi.org/10.1016/j. cjca.2016.01.024. PMid:26995692.

World Health Organization - WHO. (2014). Global status report on noncommunicable diseases 2014. Geneva: WHO.

Xavier, H. T., Izar, M. C., Faria, J. R., No., Assad, M. H., Rocha, V. Z., Sposito, A. C., Fonseca, F. A., Santos, J. E., Santos, R. D., Bertolami, M. C., Faludi, A. A., Martinez, T. L., Diament, J., Guimarães, A., Forti, N. A., Moriguchi, E., Chagas, A. C., Coelho, O. R., \& Ramires, J. A. (2013). V Diretriz Brasileira de Dislipidemias e Prevenção da Aterosclerose. Arquivos Brasileiros de Cardiologia, 101(4, Suppl 1), 1-22. http://dx.doi.org/10.5935/abc.2013S010. PMid:24217493.

Zaribaf, F., Falahi, E., Barak, F., Heidari, M., Keshteli, A. H., Yazdannik, A., \& Esmaillzadeh, A. (2014). Fish consumption is inversely associated with the metabolic syndrome. European Journal of Clinical Nutrition, 68(4), 474-480. http://dx.doi.org/10.1038/ejcn.2014.5. PMid:24549028. 